J. Appl. Glycosci., 53, 17-19 (2006)

(C) 2006 The Japanese Society of Applied Glycoscience

Note

\title{
Preparation and Differential Scanning Calorimetric Studies of a New Water-absorbing Polysaccharide from a Bacterium Belonging to the Family Oxalobacteraceae
}

\author{
(Received June 20, 2005 ; Accepted October 12, 2005) \\ Kazutoshi Ogawa, ${ }^{1}$ Kazuhide Yamasato ${ }^{2}$ and Yoshimi Maeda, ${ }^{1, *}$ \\ ${ }^{1}$ Department of Environmental Science, College of Science and Engineering, Iwaki Meisei University \\ (5-5-1, Chuodai-Iino, Iwaki 970-8551, Japan) \\ ${ }^{2}$ Department of Fermentation Sciences, Faculty of Applied Bio-Science, Tokyo University of Agriculture \\ (1-1-1, Sakuragaoka, Setagaya-ku, Tokyo 156-8502, Japan)
}

\begin{abstract}
A Gram-negative bacterium, strain IM944, belonging to the family Oxalobacteraceae which produced a new water-absorbing polysaccharide (WAP) was isolated from soil. The water-absorbing capacity of the WAP purified by the cetyltrimethylammonium bromide treatment in a potassium hydroxide solution was 120 times as much as its own weight without stickiness. The differential scanning calorimetry (DSC) of WAP showed the reversible heat transition at a peak temperature of $60.5^{\circ} \mathrm{C}$, suggesting that this polysaccharide sample is homogeneous and forms a highly ordered structure in aqueous solutions.
\end{abstract}

Key words: water-absorbing polysaccharide, new bacterium of Oxalobacteraceae, DSC analysis

In the course of our screening of water-absorbing polysaccharides, a new polysaccharide prepared from a culture of a soil bacterium has been found. In an investigation of chemical modification of carboxymethylcellulose (CMC), we found that CMC fibers having slightly been crosslinked by the treatment of dichloroacetic acid quickly absorbed water without growing sticky. ${ }^{1)}$ We took an interest in this water-absorbing property and set out to search for polysaccharides of a bacterial origin with this property, because such polysaccharides may have a specific chemical structure and morphology in water, which can be used as a biodegradable bioabsorbent similar to that reported by Kurane and Nohata. ${ }^{2)}$ In this paper, the screening, purification, and differential scanning calorimetry (DSC) analysis of the new water-absorbing polysaccharide (WAP) are reported.

A small amount of soil sample collected in Niigata Prefecture, Japan, was suspended in water, and was spread on $1.5 \%(\mathrm{w} / \mathrm{v})$ agar plates containing Czapek-Dox medium (composition (g/L): sucrose, 30; $\mathrm{K}_{2} \mathrm{HPO}_{4}, \quad$; $\mathrm{MgSO}_{4} \cdot 7 \mathrm{H}_{2} \mathrm{O}, 0.5 ; \mathrm{NaNO}_{3}, 2 ; \mathrm{KCl}, 0.5 ; \mathrm{FeSO}_{4} \cdot 7 \mathrm{H}_{2} \mathrm{O}$, 0.01 at $\mathrm{pH} 7.0$ ). After the cultivation at $30^{\circ} \mathrm{C}$ for $5 \mathrm{~d}$, colonies swelling from water absorption were picked up. Each isolate was cultured by shaking at $120 \mathrm{rpm}$ in a flask containing $80 \mathrm{~mL}$ of Czapek-Dox medium for $5 \mathrm{~d}$ at $30^{\circ} \mathrm{C}$, and then autoclaved. Three times the volume of acetone was added to the culture broth, and the precipitate obtained was washed twice with $80 \%$ aqueous acetone (v/ v) and dried by acetone substitution. Fifty-four isolates were tested for the production of extracellular materials with a water-absorbing capacity, and a bacterial strain IM 944 was selected. The $0.47 \mathrm{~g}$ precipitated by acetone (crude WAP) was yielded from $80 \mathrm{~mL}$ culture broth of

${ }^{*}$ Corresponding author (Tel. +81-246-29-7153, Fax. +81-24629-0577, E-mail: maeda@iwakimu.ac.jp). strain IM944, and the water absorption capacity was 200 times as much as its own weight without stickiness, and $\mathrm{N}$ content was $1.80 \%$ of the total weight (measured by the Institute of Science and Technology, Inc., Japan).

The taxonomic characteristics and the phylogenetic position of the strain IM944 are as follows. The organism was a Gram-negative, aerobic, non-motile rod. It was catalase positive but oxidase negative. Starch and gelatin were hydrolyzed. Reduction of nitrate, production of indole, hydrolysis of aesculine, arginine dihydrolase, $\beta$ galactosidase and urease were all negative. It assimilated L-arabinose, D-mannose, maltose, $n$-capric acid, DL-malic acid and phenyl acetate, but not D-mannitol, N-acetyl-Dglucosamine, gluconate, adipate or citrate. Acid was produced from D-glucose, D-fructose, D-mannose, maltose and sucrose, and weakly from L-arabinose, D-xylose, Dgalactose, cellobiose, raffinose, starch, glycerol and Dmannitol, but not from lactose, L-sorbitol, inositol or $\alpha$ methyl-D-glucoside. The 16S rRNA gene sequence analysis showed that the bacterium took a position in the phylogenetic radiation of the family Oxalobacteraceae. The sequence similarities of this gene between the organism and the neighboring species were $96.4 \%$ for Duganella zoogloeoides; $95.8 \%$ for Duganella violaceinigra, $95.6 \%$ for Herbaspirillum lusitanum and $95.4 \%$ for Janthinobacterium lividum. The sequence similarities among the genera Duganella, Herbaspirillum, Janthinobacterium, Massilia, Telluria and Collimonas are around 95\%. The strain IM944 exhibited distinct phenotypic features from those of the species of the above mentioned genera. Based on phylogenetic and phenotypic characteristics, the strain IM 944 should constitute a new species but can not be assigned to the hitherto described genera, probably belonging to a new genus. In the present paper, the organism was tentatively identified as a new species, phylogenetically belonging to the family Oxalobacteraceae. Exact 
taxonomic position and nomenclature of the strain awaits further isolation of similar strains and further critical taxonomic studies of the family Oxalobacteraceae at a generic level. The taxonomic tests other than motility and acid formation from carbohydrates and the phylogenetic analysis for bacterial identification were done by NCIMB Japan Co., Ltd.

The water absorption capacity of a sample was measured by the "tea bag method." Tea bags made of organic polymers (polypropylene, polyester and polyethylene) were filled with a sample $(40 \mathrm{mg})$. After the set of tea bags with and without a sample were immersed in water for $2 \mathrm{~h}$, they were taken out and left for $4 \mathrm{~min}$ on tissue wipers, and then weighed. The water absorption capacity of a sample was calculated by the difference $(\mathrm{g})$ between wet tea bag weight with and without a sample divided by the dried sample weight $(\mathrm{g})$.

The acetone precipitate (crude WAP) being substantially insoluble in water was further purified by the treatment of cetyltrimethylammonium bromide (Cetavron, Wyeth-Ayerst) in potassium hydroxide solution. ${ }^{3}$ Crude WAP (1.0 g) was added with sodium borohydride (50 $\mathrm{mg}$ ) in $4 \%$ potassium hydroxide solution $(\mathrm{w} / \mathrm{w}, 500 \mathrm{~mL})$, and stirred for $24 \mathrm{~h}$ at ambient temperature, under a nitrogen gas stream, and then $0.2 \%$ Cetavron solution $(\mathrm{w} / \mathrm{w}$, $500 \mathrm{~mL}$ ) was added to the mixture. The WPC-Cetavron complex was added with sodium chloride (20 g) and sodium borohydride $(50 \mathrm{mg})$ in $4 \%$ potassium hydroxide solution (w/w, $250 \mathrm{~mL}$ ), and was stirred for $24 \mathrm{~h}$ at ambient temperature, under a nitrogen gas stream, and then acetone $(500 \mathrm{~mL})$ was added. The precipitate obtained was neutralized and washed twice with $60 \%$ aqueous acetone solution $(\mathrm{v} / \mathrm{v})$, and then dried by acetone substitution to obtain the purified WAP $(0.20 \mathrm{~g}$ from $80 \mathrm{~mL}$ culture broth) as white fibrous powder, $\mathrm{MP}>181^{\circ} \mathrm{C}$ (gradually decomp.), $\mathrm{N}$ content $0.30 \%$, IR (KBr) $1030-1150 \mathrm{~cm}^{-1}$ (characteristic saccharide band). Its absorbing capacity was 120 times as much as its own weight without stickiness.

The purified WAP did not include uronic acids mea- sured by the method of Bitter and Muir, nor amino sugars by the method of Rondle and Morgan. ${ }^{5)}$ The purified WAP (10 mg) was hydrolyzed with $0.75 \mathrm{~mol} / \mathrm{L}$ sulfuric acid for $4 \mathrm{~h}$ at $100^{\circ} \mathrm{C}$. The hydrolysate was neutralized with barium carbonate, deionized with Dowex 50W $\left(\mathrm{H}^{+}\right.$ form) resin, evaporated to a syrup, and was converted into the corresponding alditol acetate ${ }^{6)}$ for gas-liquid chromatography (GLC). Sugar analysis by GLC (column Shimadzu CBP5 $50 \mathrm{~m} \times 0.2 \mathrm{~mm}, 220^{\circ} \mathrm{C}$, carrier gas $\mathrm{N}_{2}$ ) indicated the presence of mannose, glucose, and galactose with the molar ratio 1:3:3. To the best of our knowledge, a polysaccharide having this sugar composition and molar ratio is a new one, so the purified WAP seems to be a new type of polysaccharide.

The physicochemical properties of this polysaccharide WAP were investigated by means of differential scanning calorimetry (DSC). It is known that water-soluble polysaccharides such as schizophyllan or xanthan take stabilized and ordered structures in an aqueous solution undergoing conformational transitions during the process of temperature rising, and indicate characteristic DSC curves. ${ }^{78}$ However, such an order-disorder transition has not been reported for substantially water-insoluble substances such as water-absorbing polysaccharides. We are particularly interested in the possibility whether this WAP has a specific morphology in water and gives a characteristic DSC curve. In addition, it is also expected that such a DSC curve may provide an evidence of homogeneity of substantially water-insoluble polysaccharides which has difficulty in determination. With such interest DSC was carried out for WAP. The WAP purified as mentioned above was suspended in water with the final concentration of $0.25 \%(\mathrm{w} / \mathrm{v})$ and heated at $40^{\circ} \mathrm{C}$ for $3.5 \mathrm{~h}$ while being stirred, and allowed to stand at ambient temperature for a few days. The transparent sample solution obtained was put in the DSC sample cell and scanned at the heating rate of $0.5^{\circ} \mathrm{K} / \mathrm{min}$. The DSC curves were measured by using a differential scanning microcalorimeter model MCS DSC from Microcal Inc. (Northampton, MA, USA) attached with a $1.1644 \mathrm{~mL}$ sample vessel.

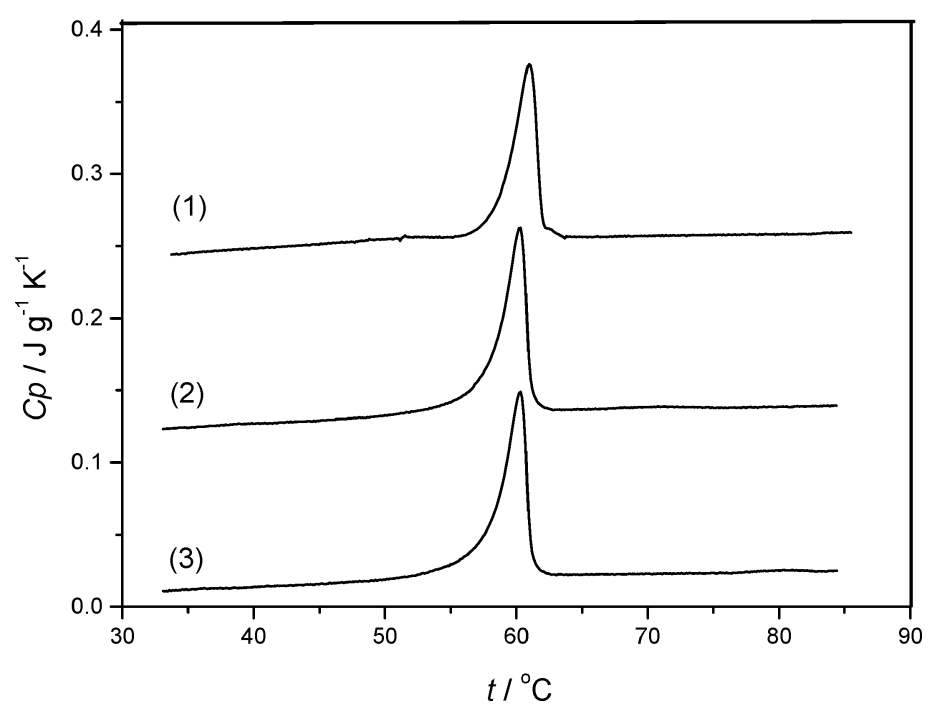

Fig. 1. DSC curves of a $0.25 \%$ WAP solution (w/v).

The sample was heated at the rate of $0.5^{\circ} \mathrm{K} / \mathrm{min}$. Heating and cooling were repeated: (1) 1st scan, (2) 2 nd scan, (3) 3rd scan. 
Figure 1 shows melting profiles of the polysaccharide obtained during the heating and cooling processes repeated three times. The endotherm in the heating trace corresponds to the transition between the ordered and disordered structures of the polysaccharide, suggesting that this polysaccharide forms a highly ordered structure in aqueous solutions similar to schizophyllan and xanthan, as was previously reported by Kitamura et al.$^{7,8)}$ The three DSC curves (1st, 2nd and 3rd) with a peak top temperature of $60.5^{\circ} \mathrm{C}$ are very similar, indicating that the orderdisorder transition of the polysaccharide is reversible, and that this sample is highly purified and homogeneous. A mean of DSC may give an evidence of the homogeneity of the substantially water-insoluble polysaccharide.

The polysaccharide (WAP) obtained in this study absorbs water quickly without growing sticky. These properties are different from those of the acidic polysaccharide reported by Kurane and Nohata, ${ }^{2)}$ which has a high water absorption capacity (more than 1000 times as much as its own weight) and a high viscosity. Structural study and detailed DSC analysis on WAP are under investigation now.

The authors wish to express their sincere thanks to Dr. Shinichi Kondo, Bioscience Associates, for his kind advice throughout this study and to Dr. Yoko Ikeda, Microbial Chemistry Research Foundation, for her technical suggestions. They also thank Mizuki Sato, Maki Owada, Yoko Nakano, Yukie Iimura, Miyuki Otsuka, Yuki Honda, Yoko Kawabe, Keiko Namekawa and Taichi Tachikawa for assisting with the experimental work. This work was supported by a Grant-in-Aid for Arrangement of High-technology Research Center, Iwaki Meisei University, from the Ministry of Education, Science, Sports and Culture of Japan.

\section{REFERENCES}

$1)$ K. Ogawa, T. Iwane, M. Kudo and S. Hayakawa: Japan Tokkyo Koho, Sho57-13666 (Mar. 18, 1982).

2 ) R. Kurane and Y. Nohata: A new water-absorbing polysaccharide from Alcaligenes latus. Biosci. Biotechnol. Biochem., 58, 235-238 (1994).

3 ) S.A. Barker, M. Stacey and G. Zweifel: The separation of neutral polysaccharides. Chem. Ind. (London), 330 (1957).

4 ) T. Bitter and H.M. Muir: A modified uronic acid carbazole reaction. Anal. Biochem., 4, 330-334 (1962).

5 ) C.J. Rondle and W.T. Morgan: The determination of glucosamine and galactosamin. Biochem. J., 61, 586-589 (1955).

6 ) B. Lindberg: Methylation analysis of polysaccharides. Methods Enzymol., 28, 178-195 (1972).

7 ) S. Kitamura and T. Kuge: A differential scanning calorimetric study of the conformational transitions of schizophyllan in mixtures of water and dimethylsulfoxide. Biopolymers, 28, 639654 (1989).

8 ) S. Kitamura, K. Takeo, T. Kuge and B.T. Stokke: Thermally induced conformational transition of double-stranded xanthan in aqueous salt solutions. Biopolymers, 31, 1243-1255 (1991).

\section{Oxalobacteraceae 科細菌 IM944 株が生成する 新規吸水性多糖の調製とその示差走査熱量測定}

小川和鋭 ${ }^{1}$, 山里一英 ${ }^{2}$, 前田好美 ${ }^{1}$

${ }^{1}$ いわき明星大学科学技術学部生命環境学科

（970-8551 いわき市中央台飯野 5-5-1）

2 東京農業大学応用生物科学部醹造科学科

（156-8502 東京都世田谷区桜丘 1-1-1）

カルボキシメチルセルロースの部分架橋により多量の 水を速やかに吸収し，かつ粘稠性を生じない性質が発現 した知見に基づき，同様の性質をもつ多糖を菌体外に生 産する細菌の検索を行った。そのような菌体外多糖は, 特異的な化学構造, あるいは, 水中での高次構造をもつ ことが，また，生分解性の吸水性物質としての応用が期 待できる。ツァペック・ドックス培地を用いて探索した 結果，土畩より，自重の 200 倍の吸水能をもつ粗多糖（粗 WAP）を生産する 1 菌株（IM944 株）を分離した。IM944 株は, 形態学的性質, 生理·生化学的性質, 16S rRNA 遺 伝子の全塩基配列解析の諸結果より，Oxalobacteraceae 科 に属する新種と推定された。また, 粗 WAPを水酸化カリ ウム水溶液中で，七チルトリメチルアンモニウムブロミ ドと処理することにより，マンノース，グルコース，ガ ラクトース (モル比 1:3:3) を構成糖とする精製多糖 (WAP) を得た. WAP は吸水倍率 120 倍, 窒素含量 $0.3 \%$ の白色, 繊維状の粉末で, ウロン酸, アミノ糖は含まれなかった. この多糖は構成糖およびそのモル比から，新規の多糖と 推定された。WAPの示差走査熱量測定（DSC）を行った 結果（Fig. 1）は, $60.5^{\circ} \mathrm{C}$ 付近に頂点のあるピークを示し た. 数回の昇降温をくり返しても，ピークの形状にほと んど変化がなかったことから，WAP は均質な試料である と判断された。また，WAPのDSC曲線が転移ピークを 示したことは，実質的に水不溶性である吸水性多糖にお いても可溶性多糖と同様に，何らかの高次構造を形成し ていることを示唆した。DSC 法は，均質性の証明が困難 な水難溶性多糖の均質性の証明法として有用である可能 性が示された。 